\title{
PENERAPAN PROBLEM BASED LEARNING DALAM KERANGKA LESSON STUDY UNTUK MENINGKATKAN KEMAMPUAN BERPIKIR KRITIS DAN HASIL BELAJAR AKUNTANSI SISWA
}

\author{
Imam Baidillah \\ Anita Srie Utami M \\ SMK Negeri 1 Malang \\ mam.baid@gmail.com
}

\begin{abstract}
The research was conducted with the aim to describe learning process by using the Poblem Based Learning (PBL) method within the lesson study framework to improve critical thinking skills and learning outcomes for the eleventh grade students of Accounting at SMK 1 Malang. This is a Classroom Action Research (CAR) with the subject of eleventh grade students of Accounting 3 at SMK Negeri 1 Malang that consist of 36 students. During the PBL implementation, there was observation on the critical thinking skills of students by 5 team members. Written test was conducted to measure cognitive aspects. The results showed that the implementation of PBL integrated with lesson study can improve critical thinking skills and student learning outcomes.
\end{abstract}

Keywords: Problem Based Learning (PBL), lesson study, critical thinking ability, learning outcome, accounting

Abstrak: Penelitian ini dilaksanakan dengan tujuan untuk mendeskripsikan proses pembelajaran dengan menggunakan metode PBL dalam kerangka lesson study dalam meningkatkan kemampuan berpikir kritis dan hasil belajar siswa kelas XI Akuntansi SMK Negeri 1 Malang. Penelitian ini merupakan penelitian tindakan kelas (PTK) dengan subjek siswa kelas XI Akuntansi 3 SMK Negeri 1 Malang berjumlah 36 siswa. Selama pelaksanaan PBL dilakukan observasi terhadap kemampuan berpikir kritis siswa oleh 5 anggota tim lesson study. Untuk melihat hasil belajar siswa pada aspek kognitif dilakukan tes tertulis dengan soal berbentuk pilihan ganda. Hasil penelitian menunjukkan bahwa penerapan PBL dalam kerangka lesson study dapat meningkatkan kemampuan berpikir kritis dan hasil belajar siswa.

Kata Kunci: Problem Based Learning (PBL), lesson study, kemampuan berpikir kritis, hasil belajar, akuntansi

Proses pembelajaran yang berpusat pada siswa (Student Centered Learning) merupakan pendekatan yang memungkinkan siswa berpartisipasi secara aktif, selalu ditantang untuk memiliki daya kritis, mampu menganalisa dan dapat memecahkan masalahnya sendiri. Pada kenyataannya masih banyak guru yang mendominasi jalannya proses pembelajaran (Teacher Centered Learning) dan siswa dikondisikan pasif menerima pengetahuan. Jika hal ini dilakukan secara terus menerus, maka kondisi pembelajaran di dalam kelas tidak dapat berkembang. Siswa tidak terbiasa mengemukakan pendapatnya ketika menghadapi suatu permasalahan. Dalam pembelajaran seharusnya siswa diarahkan untuk dapat mengembangkan kemampuan berpikir kritis dalam menyelesaikan berbagai masalah.

Kemampuan berpikir kritis merupakan kemampuan yang sangat esensial untuk kehidupan, pekerjaan, dan berfungsi efektif dalam semua aspek kehidupan lainnya. Berpikir kritis telah lama 
menjadi tujuan pokok dalam pendidikan. Kemampuan berpikir kritis diperlukan dalam pembelajaran akuntansi. Akuntansi (accounting) adalah suatu sistem informasi yang mengidentifikasikan, mencatat, dan mengkomunikasikan peristiwa-peristiwa ekonomi dari suatu organisasi kepada para pengguna yang berkepentingan (Kieso, dkk, 2009: 4).

Salah satu unsur vital dalam mengkomunikasikan peristiwa-peristiwa ekonomi adalah kemampuan akuntan untuk menganalisis dan menginterpretasikan informasi yang telah dilaporkan. Analisis meliputi penggunaan rasio, persentase, grafik, dan diagram untuk menyoroti tren-tren dan hubungan keuangan yang signifikan. Interpretasi meliputi penjelasan kegunaan, maksud, dan keterbatasan data yang dilaporkan (Kieso, 2009: 5).

Berdasarkan definisi dan alur aktivitas akuntansi tersebut, maka dalam pembelajaran akuntansi selain pemahaman terhadap konsep juga ditekankan pada pentingnya mengembangkan kemampuan berpikir dan memecahkan masalah. Salah satu kemampuan berpikir yang perlu dikembangkan adalah kemampuan berpikir kritis. Berdasarkan artikel yang ditulis oleh Reinstein dan Bayou (1997) dengan judul Critical Thinking in Accounting Education: Processes, Skills, and Applications, pendidikan akuntansi harus menyediakan siswa dengan keterampilan dan kemampuan yang memadai dan berguna di masa depan, termasuk komunikasi yang kuat, analisis kuantitatif, interpersonal dan keterampilan intelektual. Siswa akuntansi dituntut untuk menganalisis, mensintesis, dan menilai secara kritis faktor yang relevan dengan menggunakan bukti yang ada secara efektif (Reinstein dan Bayou, 1997: 339).

Hasil observasi di lapangan dan wawancara dengan guru mata pelajaran siklus akuntansi perusahaan dagang di kelas XI Akuntansi 3 SMK Negeri 1 Malang menunjukkan bahwa siswa belum memiliki kemampuan berpikir secara optimal. Hal ini dapat dilihat dari proses pembelajaran siswa cenderung kurang mampu mengamati, merumuskan masalah, membuat pernyataan yang jelas dari setiap pertanyaan, merencanakan percobaan, dan mengembangkan ide melalui berbagai alternatif. Kondisi tersebut berpengaruh pada hasil belajar siswa. Terlihat bahwa nilai rata-rata kelas masih di bawah standar kelulusan minimum sebesar 72,5. Ini menunjukkan bahwa tingkat kemampuan berpikir kritis dan hasil belajar siswa tersebut masih rendah.

Salah satu cara untuk mengembangkan kemampuan berpikir kritis siswa adalah dengan memilih model pembelajaran yang dapat memacu siswa secara aktif ikut terlibat dalam pengalaman belajarnya. Salah satu model yang dapat diterapkan adalah model problem based learning (PBL). Model PBL dapat membuat siswa aktif dan mampu mengoptimalkan kemampuan berpikir mereka, tidak hanya pasif dalam menerima penjelasan yang disampaikan guru. Dalam model PBL siswa dituntut secara aktif mengembangkan kemampuan berpikir mereka untuk merumuskan masalah dan mencari solusi dalam pemecahan masalahnya, sehingga dapat mengembangkan keterampilan berpikir kritis mereka.

Dalam proses PBL, kegiatan yang dilakukan oleh guru adalah menghadirkan permasalahan dunia nyata di dalam kelas yang tentunya berkaitan dengan materi atau indikator yang akan dicapai, sehingga siswa akan terlibat langsung dalam memecahkan masalah yang ada dengan menggunakan keterampilan serta pengalaman yang dimiliki oleh masing-masing siswa. Permasalahan dalam pendekatan ini menjadi komponen yang sangat penting, karena tema-tema permasalahan yang dirancang harus mencakup semua tuntutan kurikulum (Barrow dan Myers dalam Mukhlis, dkk. 2005: 13). Peran guru dalam proses ini adalah memacu siswa untuk berpikir kritis dalam memberikan solusi terhadap permasalahan yang ada. PBL dikembangkan terutama untuk membantu siswa mengembangkan kemampuan berpikir, memecahkan masalah dan keterampilan intelektual, belajar tentang berbagai peran orang dewasa melalui pelibatan mereka dalam pengalaman nyata atau simulasi dan menjadi pembelajar yang otonom dan mandiri (Nurhadi, dkk. 2004: 58).

Riyanto (2009: 285) menyatakan "PBL adalah suatu model pembelajaran yang menuntut peserta didik untuk berpikir kritis, memecahkan masalah, belajar secara mandiri, dan menuntut 
keterampilan berpartisipasi dalam tim". Masalah menjadi poin penting dalam model PBL. Diterapkannya model PBL diyakini dapat mengembangkan kemampuan berpikir kritis siswa dalam memecahkan masalah berupa soal transaksi-transaksi yang ada di perusahaan, yaitu melalui perumusan masalah, bertanya dan menjawab pertanyaan, melakukan diskusi, menghargai orang lain, melakukan kredibilitas (menganalisis, mensintensis, dan menilai secara kritis) sumber informasi, melakukan observasi, mengambil keputusan, dan mengevaluasi hasil laporannya.

Pada sisi lain lesson study merupakan suatu model pembinaan profesi pendidik melalui pengkajian pembelajaran secara kolaboratif dan berkelanjutan berlandaskan prinsip-prinsip kolegalitas dan mutual learning untuk membangun learning community (Siddik: 2013). Lesson study bukan suatu metode pembelajaran atau strategi pembelajaran, tetapi dalam kegiatan lesson study dapat memilih dan menerapkan berbagai metode/trategi pembelajaran yang sesuai dengan situasi, kondisi, dan permasalahan yang dihadapi pendidik. Lesson study dapat merupakan suatu kegiatan pembelajaran dari sejumlah guru dan pakar pembelajaran yang mencakup 3 (tiga) tahap kegiatan, yaitu perencanaan (planning), implementasi (action) pembelajaran dan observasi serta refleksi (reflection) terhadap perencanaan dan implementasi pembelajaran tersebut, dalam rangka meningkatkan kualitas pembelajaran (Siddik: 2013).

Lesson study dipilih dan diimplementasikan karena beberapa alasan. Pertama, lesson study merupakan suatu cara efektif yang dapat meningkatkan kualitas pembelajaran yang dilakukan guru dan aktivitas belajar siswa. Hal ini karena (1) pengembangan lesson study dilakukan dan didasarkan pada hasil "sharing" pengetahuan profesional yang berlandaskan pada praktik dan hasil pengajaran yang dilaksanakan para guru, (2) penekanan mendasar pada pelaksanaan suatu lesson study adalah agar para siswa memiliki kualitas belajar, (3) kompetensi yang diharapkan dimiliki siswa, dijadikan fokus dan titik perhatian utama dalam pembelajaran di kelas, (4) berdasarkan pengalaman real di kelas, lesson study mampu menjadi landasan bagi pengembangan pembelajaran, dan (5) lesson study akan menempatkan peran para guru sebagai peneliti pembelajaran (Lewis, 2002 dalam Siddik, 2013). Kedua, lesson study yang didesain dengan baik akan menjadikan guru yang profesional dan inovatif. Dengan melaksanakan lesson study para guru dapat (1) menentukan kompetensi yang perlu dimiliki siswa, merencanakan dan melaksanakan pembelajaran (lesson) yang efektif; (2) mengkaji dan meningkatkan pelajaran yang bermanfaat bagi siswa; (3) memperdalam pengetahuan tentang mata pelajaran yang disajikan para guru; (4) menentukan standar kompetensi yang akan dicapai para siswa; (5) merencanakan pelajaran secara kolaboratif; (6) mengkaji secara teliti belajar dan perilaku siswa; (7) mengembangkan pengetahuan pembelajaran yang dapat diandalkan; dan (8) melakukan refleksi terhadap pengajaran yang dilaksanakannya berdasarkan pandangan siswa dan koleganya (Lewis, 2002 dalam Siddik, 2013). Dengan melaksanakan lesson study aktivitas belajar siswa dalam belajar menjadi lebih kondusif dan termotivasi dalam mengikuti proses pembelajaran. Lesson study merupakan suatu cara yang efektif yang dapat meningkatkan kualitas mengajar guru dan pada akhirnya akan meningkatkan hasil belajar siswa.

Berdasarkan pemaparan di atas dapat disimpulkan bahwa dalam proses belajar mengajar diperlukan metode pembelajaran yang mampu memberikan dampak yang baik terutama dalam meningkatkan kemampuan berpikir kritis dan hasil belajar. Penelitian ini dilakukan untuk mengetahui bagaimana penerapan PBL dan apakah PBL dapat meningkatkan kemampuan berpikir kritis dan hasil belajar siswa. Sebelum adanya model pembelajaran PBL ini guru lebih sering menggunakan metode ceramah dalam proses pembelajarannya. Sedangkan lesson study diharapkan dapat meningkatkan kualitas pembelajaran baik dari sisi siswa maupun guru. Maka penelitian ini diberi judul Penerapan Problem Based Learning dalam Kerangka Lesson Study untuk Meningkatkan Kemampuan Berpikir Kritis dan Hasil Belajar Siswa Kelas XI Akuntansi SMK Negeri 1 Malang. 


\section{METODE}

Pendekatan penelitian ini menggunakan pendekatan kualitatif. Pendekatan kualitatif dipilih untuk memahami fenomena tentang apa yang dialami oleh subjek penelitian misalnya: perilaku, persepsi, motivasi, dan tindakan secara holistik dan dengan cara deskripsi dalam bentuk kata-kata dan bahasa pada suatu konteks khusus yang alamiah dengan memanfaatkan berbagai metode ilmiah (Moleong, 2002:6). Jenis penelitian ini adalah penelitian tindakan kelas (classroom action research) karena digunakan untuk memecahkan masalah-masalah yang terjadi dalam kegiatan pembelajaran. Menurut Arikunto, dkk (2009: 3) "penelitian tindakan kelas merupakan suatu pencermatan terhadap kegiatan belajar berupa sebuah tindakan yang sengaja dimunculkan dan terjadi dalam sebuah kelas secara bersama".

Pada penelitian ini peneliti bertindak sebagai pelaksana kegiatan, perencana kegiatan, pengumpul data yang diperoleh dari observasi terhadap siswa pada saat kegiatan pembelajaran berlangsung sekaligus sebagai penganalisis data dan pelapor hasil penelitian. Dalam setiap tahapan penelitian, peneliti berkolaborasi dengan anggota tim lesson study.

Penelitian ini dilaksanakan di kelas XI Akuntansi 3 SMK Negeri 1 Malang, Jl. Sonokembang, Janti, Sukun Kota Malang. Penelitian dilakukan pada bulan Maret-April tahun 2015 di SMK Negeri 1 Malang. Subjek dalam penelitian ini adalah siswa kelas XI Akuntansi 3 pada Semester 4 (genap) Tahun Pelajaran 2014./2015 dengan jumlah 36 orang yang terdiri dari semua siswa perempuan dengan kemampuan yang heterogen.

Data yang akan diambil dalam penelitian ini meliputi; (1) penerapan PBL dalam kerangka lesson study, (2) kemampuan berpikir kritis siswa, dan (3) hasil belajar siswa. Pengumpulan data yang digunakan dalam penelitian ini adalah: (1) soal tes; (2) lembar observasi; (3) catatan lapangan/pengamatan; dan (3) dokumentasi. Analisis data yang digunakan adalah: (1) reduksi data; (2) penyajian data; dan (3) kesimpulan dan refleksi. Data yang akan dianalisis adalah: (1) lembar observasi guru dan siswa dalam penerapan PBL; (2) lembar observasi kemampuan berpikir kritis siswa; dan (3) hasil belajar ranah kognitif, afektif dan psikomotorik.

Tahap-tahap pada penelitian ini dilakukan dengan penggabungan antara desain PTK dengan skema kegiatan lesson study.

\section{Penelitian Tindakan Kelas}

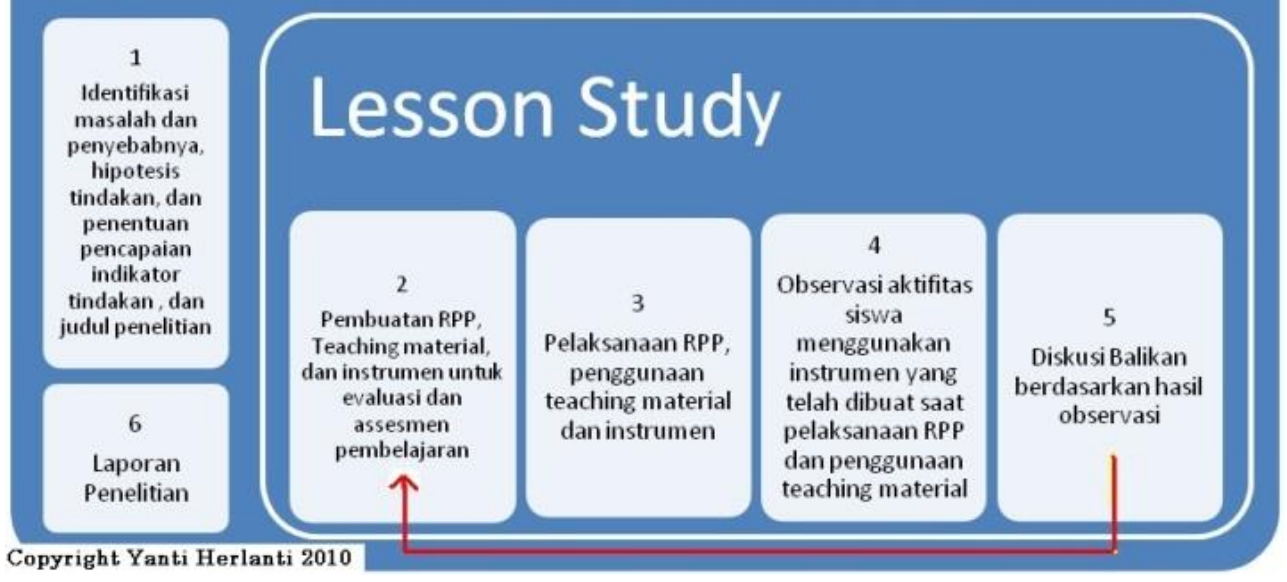

Gambar 1. Penggabungan Kegiatan Penelitian Tindakan Kelas dan Lesson Study (Sumber: Herlanti, 2010). 
Indikator keberhasilan penelitian tindakan kelas ini adalah bahwa kemampuan berpikir kritis siswa kelas XI Akuntansi dapat dikatakan optimal jika berdasarkan hasil observasi kemampuan berpikir kritis menunjukkan $80 \%$ siswa berada dalam kategori minimal baik dan terjadinya peningkatan hasil belajar yang ditinjau dari hasil post-test yaitu jika skor rata-rata hasil belajar siswa mengalami peningkatan dan atau $80 \%$ siswa berada pada kategori minimal baik setelah penerapan PBL dalam kerangka lesson study. Jika indikator keberhasilan belum tercapai pada siklus I, maka akan dilanjutkan pada siklus II dan berikutnya sampai indikator keberhasilan penelitian tercapai.

\section{HASIL DAN PEMBAHASAN}

PBL dilaksanakan dalam kerangka lesson study artinya penerapan PBL didampingi oleh anggota tim lesson study mulai dari tahapan perencanaan (plan), pelaksanaan dan pengamatan (do) hingga refleksi (see).

Pada tahap perencanaan (plan), peneliti bersama anggota tim lesson study secara kolaboratif menyusun dan mempersiapkan format-format, deskripsi tugas, serta tata tertib yang diperlukan pada kegiatan lesson study. Format yang disiapkan meliputi format pengamatan dan tata tertib pelaksanaan lesson study. Format ini disusun untuk mendokumentasikan segala kegiatan lesson study sehingga dapat dilakukan refleksi yang akurat. Selain itu, anggota tim lesson study juga merencanakan dan menyusun perangkat pembelajaran lengkap dan perangkat instrumen untuk keperluan tahap pelaksanaan (plan), yaitu penyusunan Rencana Pelaksanaan Pembelajaran (RPP), handout materi, Lembar Kegiatan Siswa (LKS), lembar observasi kegiatan guru dan siswa dalam PBL, lembar observasi kemampuan berpikir kritis siswa, dan penyusunan soal tes. Tugas anggota tim lesson study juga dibagi, yaitu sebagai moderator dan notulen pada tahap perencanaan (plan) dan refleksi (see), sebagai guru model, pengamat/observer, dan kameramen/dokumentasi pada tahap pelaksanaan (do). Hal terakhir yang dilakukan adalah menentukan jadwal pelaksanaan (do) dan refleksi (see).

Pada tahap pelaksanaan dan pengamatan $(d o)$, pelaksanaan pembelajaran dibagi menjadi tiga kegiatan yaitu kegiatan awal, kegiatan inti yang terdiri dari 5 tahapan yaitu (1) orientasi siswa kepada masalah; (2) mengorganisasi siswa untuk belajar; (3) membimbing penyelidikan individual dan kelompok; (4) mengembangkan dan menyajikan hasil karya; dan (5) menganalisa dan mengevaluasi proses pembelajaran, dan kegiatan akhir. Hal ini sesuai dengan RPP dengan model PBL, dengan bantuan 5 orang anggota tim lesson study akan mengamati dan mengobservasi setiap kegiatan yang dilaksanakan guru dan siswa dalam proses pembelajaran.

Pada kegiatan awal, guru model mengucapkan salam, memimpin doa, mengabsen, dan melakukan apersepsi yaitu menyampaikan tujuan pembelajaran yang bertujuan untuk memotivasi siswa. Selanjutnya masuk ke kegiatan inti yaitu menerapkan tahapan dalam PBL. Tahapan yang pertama adalah orientasi siswa kepada masalah, guru model meminta siswa membentuk kelompok heterogen (dari sisi kemampuan, gender, budaya, maupun agama) sesuai pembagian kelompok yang telah direncanakan oleh guru model. Selanjutnya, guru model membagikan LKS yang berisikan permasalahan dan langkah-langkah pemecahan serta meminta siswa berkolaborasi dengan kelompoknya untuk menyelesaikan masalah. Tahapan yang kedua yaitu mengorganisasi siswa untuk belajar, guru model mendorong siswa untuk bekerjasama dalam kelompok, guru model meminta siswa bekerjasama untuk menghimpun berbagai sumber yang sudah dipelajari serta memikirkan secara cermat strategi pemecahan yang berguna untuk memecahkan masalah. Tahapan yang ketiga yaitu membimbing penyelidikan-penyelidikan individual dan kelompok. Pada tahapan ini guru model berkeliling mencermati siswa bekerja, mencermati dan menemukan berbagai kesulitan yang dialami siswa, serta memberikan kesempatan kepada siswa untuk 
bertanya hal-hal yang belum dipahami. Guru model memberi bantuan (scaffolding) berkaitan kesulitan yang dialami siswa secara individu, kelompok, atau klasikal. Selanjutnya, guru model membimbing siswa untuk membuat contoh kasus untuk membuktikan kebenaran dari jawabannya. Tahapan yang keempat yaitu mengembangkan dan menyajikan hasil karya, guru model meminta siswa menyiapkan laporan hasil diskusi kelompok secara rapi, rinci, dan sistematis, guru model berkeliling mencermati siswa bekerja menyusun laporan hasil diskusi, dan memberi bantuan bila diperlukan. Selanjutnya guru model meminta siswa menentukan perwakilan kelompok secara musyawarah untuk menyajikan (mempresentasikan) laporan di depan kelas, guru model meminta semua kelompok bermusyawarah untuk menentukan urutan kelompok yang akan mempresentasikan (mengkomunikasikan) hasil diskusinya di depan kelas secara runtun, sistematis, santun, dan hemat waktu. Dan tahapan yang kelima atau yang terakhir yaitu menganalisa dan mengevaluasi proses pemecahan masalah, guru model memberi kesempatan kepada siswa dari kelompok penyaji untuk memberikan penjelasan tambahan dengan baik, guru model memberi kesempatan kepada siswa dari kelompok lain untuk memberikan tanggapan terhadap hasil diskusi kelompok penyaji dengan sopan, guru model melibatkan siswa mengevaluasi jawaban kelompok penyaji serta masukan dari siswa lain dan membuat kesepakatan, bila jawaban yang disampaikan siswa sudah benar, guru model memberi kesempatan kepada kelompok lain yang mempunyai jawaban berbeda dari kelompok penyaji pertama untuk mengkomunikasikan hasil diskusi kelompoknya secara runtun, sistematis, santun, dan hemat waktu. Selanjutnya, dengan tanya jawab guru model mengarahkan semua siswa pada kesimpulan mengenai pemecahan permasalahan tersebut. Setelah semuanya selesai, masuk pada bagian penutup pembelajaran. Kegiatan yang dilakukan adalah guru model meminta siswa untuk memberikan kesimpulan dan meminta siswa untuk memberikan pendapat mengenai pembelajaran yang baru saja dilakukan. Setelah itu, guru model mengakhiri kegiatan pembelajaran dengan memberikan pesan untuk tetap belajar dan mengucapkan salam.

Pada tahap Refleksi (See), dilaksanakan refleksi terhadap hasil pembelajaran sesuai dengan pelaksanaan kegiatan lesson study yaitu dengan menganalisis keseluruhan pembelajaran yang terlaksana. Pada tahap ini secara bersama-sama dilaksanakan oleh semua komponen yang hadir baik kelompok guru mata pelajaran dan observer, karena hasil diskusi dan analisis dapat dijadikan sebagai bahan masukan untuk memperbaiki atau merevisi pembelajaran selanjutnya. Tahapan refleksi (see) merupakan kegiatan diskusi formal yang membahas hasil pengamatan terhadap pelaksanaan pembelajaran oleh guru model. Diskusi ini dipimpin oleh seorang moderator dan dibantu oleh notulen. Pada tahap refleksi ini terlebih dahulu guru model diberi kesempatan untuk menceritakan proses pembelajarannya. Selanjutnya, pengamat berbagi informasi mengenai pembelajaran yang dilakukan. Pengamat menggunakan informasi untuk menjelaskan bagaimana siswa berpikir, belajar, berpartisipasi, dan berperilaku. Pengamat mempertanyakan sejauhmana tujuan pembelajaran dan pengembangan diri siswa telah diupayakan secara maksimal pencapaiannya, kemudian anggota tim lesson study pada tahap refleksi ini bersama-sama mendiskusikan kekuatan dan kelemahan pelaksanaan pembelajaran dan bersama-sama menyimpulkan hasil dan mengusulkan rekomendasi untuk perbaikan pembelajaran berikutnya.

Hasil refleksi (see) yang dilaksanakan anggota tim lesson study pada siklus I adalah sebagai berikut: (a) hasil observasi keterlaksanaan pembelajaran oleh siswa diperoleh hasil persentase rata-rata pelaksanaan pembelajaran oleh siswa sebesar $80,15 \%$ atau pada kategori baik; (b) observasi keterlaksanaan pembelajaran oleh guru diperoleh skor rata-rata total $87,78 \%$ disimpulkan bahwa pembelajaran yang dilakukan guru berada dalam kategori baik; (c) observasi kemampuan berpikir kritis siswa diperoleh skor rata-rata total 69,33\% terdapat 17 siswa dalam kategori baik dan 19 siswa dalam kategori cukup; (d) berdasarkan hasil dari pre-test siswa yang tuntas sebelum tindakan sebanyak 12 siswa $(33,33 \%)$ dan siswa yang tidak tuntas sebanyak 24 siswa $(66,67 \%)$ dengan nilai rata-rata 73,47 dan berdasarkan hasil post-test dapat diketahui 
bahwa siswa yang tuntas sebanyak 26 siswa $(72,22 \%)$ dan siswa yang tidak tuntas sebanyak 10 siswa $(27,78 \%)$ dengan nilai rata-rata 81,39 . Dari hasil pre-test dan post-test dapat dilihat bahwa hasil belajar siswa terjadi peningkatan sebesar 7,92\%. Hasil rata-rata penilaian afektif siswa sebesar 79,75\% dan hasil rata-rata penilaian psikomotorik siswa sebesar 74,31\%. Maka rata-rata hasil belajar siswa ranah kognitif, afektif dan psikomotorik sebesar 78,48\% atau dapat dikatakan bahwa hasil belajar siswa pada siklus I dalam kategori cukup; (e) permasalahan yang ditemukan pada siklus I adalah pada pertemuan 1, siswa masih kurang aktif dalam diskusi kelompok dan diskusi kelas. Siswa masih kurang terbiasa dengan pembelajaran berkelompok apalagi dengan kelompok yang tidak sesuai dengan keinginan siswa. Siswa masih cederung untuk bekerja secara individu dan menanyakan kesulitan langsung kepada guru bukan didiskusikan terlebih dahulu dengan anggota kelompok. Pengaturan waktu kegiatan oleh guru belum efektif, terutama untuk waktu diskusi dan waktu untuk presentasi. Saat diskusi, guru kurang memberikan penegasan waktu yang diberikan untuk diskusi, sehingga siswa mengulur-ulur waktu diskusi. Begitu juga dengan presentasi, guru kurang memberikan pengaturan waktu sehingga ada waktu-waktu kosong yang dimanfaatkan siswa untuk becanda sendiri. Siswa masih sulit untuk mengungkapkan alasan terhadap jawaban yang telah diberikan, masih malu untuk bertanya, menjawab pertanyaan maupun memberi tanggapan. Kemampuan berpikir kritis untuk indikator melakukan diskusi dan menghargai orang lain mendapatkan skor terendah dibandingkan dengan indikator kemampuan berpikir kritis lainnya; (f) kriteria keberhasilan dari penelitian yaitu hasil observasi kemampuan berpikir kritis menunjukkan $80 \%$ siswa berada dalam kategori minimal baik dan hasil belajar menunjukkan $80 \%$ siswa berada dalam kategori minimal baik, pada siklus 1 belum terpenuhi sehingga tindakan akan diulang pada siklus II.

Kegiatan yang akan dilaksanakan pada siklus II adalah sesuai dengan tahapan lesson study yaitu, kegiatan perencanaan (plan), tindakan dan observasi/pengamatan (do), refleksi dan evaluasi (see). Kegiatan perencanaan (plan) pada siklus II didasarkan pada hasil refleksi dan evaluasi (see) pada siklus I. Kegiatan tindakan dan observasi/pengamatan (do) untuk melaksanakan tindakan sesuai dengan perencanaan yang telah dilakukan dan melakukan observasi oleh observer anggota tim lesson study. Kegiatan evaluasi dan refleksi (see) untuk mengetahui pelaksanaan tindakan pada siklus II.

Hasil refleksi (see) yang dilaksanakan anggota tim lesson study pada siklus II adalah sebagai berikut: (a) hasil observasi keterlaksanaan pembelajaran oleh siswa dilakukan oleh 5 orang observer, pelaksanaan pembelajaran oleh siswa mendapat persentase rata-rata total sebesar 91,82\% atau dapat dikatakan berada pada kategori sangat baik; (b) observasi kegiatan guru dilakukan oleh 5 orang observer, hasil observasi pelaksanaan pembelajaran oleh guru mendapat skor rata-rata total $97,08 \%$ atau dapat disimpulkan bahwa pembelajaran yang dilakukan guru berada dalam kategori sangat baik; (c) observasi kemampuan berpikir kritis siswa dilakukan oleh 5 orang observer, hasil observasi diperoleh skor rata-rata total 85,58\%, $16(44,44 \%)$ siswa dalam kategori sangat baik dan $20(55,56 \%)$ siswa dalam kategori baik. Dapat disimpulkan bahwa kemampuan berpikir kritis siswa berada dalam kategori baik; (d) berdasarkan hasil post-test dapat diketahui bahwa semua siswa telah tuntas (100\%) dengan nilai rata-rata 91,25 (lampiran 10). Dari post-test siklus I dan post-test siklus II dapat dilihat bahwa hasil belajar siswa terjadi peningkatan sebesar 9,86\%. Hasil rata-rata penilaian afektif siswa sebesar 93,29\% (lampiran 11) dan hasil rata-rata penilaian psikomotorik siswa sebesar 88,19\% (lampiran 12). Maka rata-rata hasil belajar siswa ranah kognitif, afektif dan psikomotorik sebesar 90,91\% atau dapat dikatakan bahwa hasil belajar siswa pada siklus II dalam kategori sangat baik; (e) dalam penelitian pada siklus 2 ini ditemukan beberapa hal, diantaranya, kelompok-kelompok yang sebelumnya belum aktif, pada siklus kedua ini sudah lebih aktif untuk melakukan diskusi dan bertukar pendapat dan bekerja sama dengan baik, pengaturan waktu pada tahapan-tahapan pembelajaran sudah efektif, siswa sudah leluasa untuk mengungkapkan ide dengan lancar, jelas dan menggunakan bahasa yang tepat, kemampuan berpikir kritis untuk indikator melakukan diskusi dan menghargai orang 
lain sudah meningkat dalam kategori baik tetapi masih mendapatkan skor terendah dibandingkan dengan indikator kemampuan berpikir kritis lainnya; dan (f) kriteria keberhasilan dari penelitian yaitu hasil observasi kemampuan berpikir kritis menunjukkan $80 \%$ siswa berada dalam kategori minimal baik dan hasil belajar menunjukkan $80 \%$ siswa berada dalam kategori minimal baik, pada siklus II sudah terpenuhi sehingga tindakan dihentikan pada siklus II.

Hasil penelitian pada siklus I dan II menunjukkan bahwa penerapan PBL dalam kerangka lesson study di kelas XI Akuntansi 3 SMK Negeri 1 Malang berhasil dilaksanakan dengan baik. Berdasarkan hasil observasi keterlaksanaan pembelajaran, penerapan PBL dalam kerangka lesson study pada siklus II lebih baik dibandingkan pada penerapan siklus I. PBL dilaksanakan dalam kerangka lesson study tujuannya adalah sebagai upaya peningkatan kualitas PBL. Hal ini sesuai dengan pendapat Lewis dalam Syamsuri dan Ibrohim (2008: 31) yang menyatakan bahwa "lesson study dipilih dan diiplementasikan karena beberapa alasan. Pertama, lesson study merupakan suatu cara efektif yang dapat meningkatkan kualitas belajar dan mengajar serta pelajaran di kelas". Hal itu benar karena, (1) pengembangan lesson study dilakukan dan didasarkan pada hasil sharing pengetahuan professional yang berlandaskan pada praktek dan hasil pengajaran yang dilaksanakan para guru; (2) penekanan mendasar pada suatu lesson study adalah para siswa memiliki kualitas belajar, (3) tujuan pelajaran dijadikan fokus dan titik perhatian utama dalam pembelajaran di kelas; (4) berdasarkan pengalaman riil di kelas, lesson study mampu menjadi landasan bagi pengembangan pembelajaran; (5) lesson study menempatkan peran para guru sebagai peneliti pembelajaran. Lesson study yang didesain dengan baik akan menghasilkan guru yang professional dan inovatif. Dengan melaksanakan lesson study para guru dapat, (1) menentukan tujuan pembelajaran (lesson) satuan (unit) pelajaran, dan mata pelajaran yang efektif; (2) mengkaji dan meningkatkan pelajaran yang bermanfaat bagi siswa; (3) memperdalam pengetahuan tentang mata pelajaran yang disajikan para guru; (4) menentukan tujuan jangka panjang yang akan dicapai para siswa; (5) menentukan pelajaran secara kolaboratif; (6) mengkaji secara teliti belajar dan perilaku siswa.

Hasil penelitian pada siklus I dan II menunjukkan bahwa PBL dalam kerangka lesson study dapat meningkatkan kemampuan berpikir kritis siswa. Hal ini dapat dilihat dari hasil observasi, pada siklus I kemampuan berpikir kritis siswa pada skor rata-rata 69,33 atau dalam kategori cukup, skor terendah pada indikator melakukan diskusi dan menghargai orang lain dengan skor 63,75 dan 62,85 sedangkan pada siklus II kemampuan berpikir kritis siswa pada skor rata-rata 85,58 atau dalam kategori baik, skor terendah masih pada indikator melakukan diskusi dan menghargai orang lain dengan skor 79,51 dan 78,89.

Tabel 1. Perbandingan Persentase Kemampuan Berpikir Kritis

\begin{tabular}{|c|c|c|c|c|}
\hline & \multirow[b]{2}{*}{ Indikator } & \multicolumn{2}{|c|}{ Persentase } & \multirow{2}{*}{$\begin{array}{c}\text { Peningkatan (\%) } \\
\text { II-1 }\end{array}$} \\
\hline & & $\begin{array}{c}\text { Siklus } \\
\text { I }\end{array}$ & Siklus II & \\
\hline \multicolumn{2}{|c|}{ Merumuskan Masalah } & 67.08 & 89.38 & 22.30 \\
\hline \multicolumn{2}{|c|}{ Keterampilan Bertanya } & 64.51 & 84.93 & 20.42 \\
\hline \multicolumn{2}{|c|}{ Keterampilan Menjawab Pertanyaan } & 64.51 & 81.74 & 17.23 \\
\hline \multicolumn{2}{|c|}{ Melakukan Diskusi } & 63.75 & 79.51 & 15.76 \\
\hline \multicolumn{2}{|c|}{ Menghargai Orang Lain } & 62.85 & 78.89 & 16.04 \\
\hline \multirow{2}{*}{$\begin{array}{l}\text { Melakukan } \\
\text { Kredibilitas } \\
\text { (menganalisis, } \\
\text { mensintesis, dan } \\
\text { menilai secara } \\
\text { kritis) Sumber } \\
\text { informasi }\end{array}$} & $\begin{array}{l}\text { a. Kelebihan dan kelemahan system } \\
\text { periodik dan perpetual dalam } \\
\text { pencatatan persediaan barang } \\
\text { dagang }\end{array}$ & 79.44 & 94.58 & 15.14 \\
\hline & $\begin{array}{l}\text { b. Dampak system periodik dan } \\
\text { perpetual dalam pencatatan } \\
\text { persediaan barang dagang terhadap } \\
\text { laporan keuangan }\end{array}$ & 80.69 & 94.72 & 14.03 \\
\hline
\end{tabular}




\begin{tabular}{|c|c|c|c|c|}
\hline & $\begin{array}{l}\text { c. Sistem pencatatan persediaan } \\
\text { barang dagang yang sebaiknya } \\
\text { digunakan }\end{array}$ & 72.57 & 88.75 & 16.18 \\
\hline & $\begin{array}{l}\text { d. Metode untuk menentukan HPP } \\
\text { dan menilai persediaan akhir }\end{array}$ & 65.69 & 84.58 & 18.89 \\
\hline & $\begin{array}{l}\text { e. Bukti transaksi untuk menentukan } \\
\text { HPP dan menilai persediaan akhir }\end{array}$ & 63.89 & 82.01 & 18.12 \\
\hline Melakukan Observasi & & 76.04 & 84.93 & 8.89 \\
\hline Mengambil Keputusan & & 74.72 & 86.04 & 11.32 \\
\hline Mengevaluasi Hasil Le & aporan & 65.63 & 82.50 & 16.87 \\
\hline
\end{tabular}

Penerapan PBL dalam kerangka lesson study dapat meningkatkan kemampuan berpikir kritis karena PBL dapat membuat siswa aktif dan mampu mengoptimalkan kemampuan berpikir mereka, siswa tidak hanya pasif dalam menerima penjelasan yang disampaikan guru. Dalam PBL siswa dituntut secara aktif mengembangkan kemampuan berpikir mereka untuk merumuskan masalah dan mencari solusi dalam pemecahan masalahnya, sehingga dapat mengembangkan keterampilan berpikir kritis mereka. Hal ini sesuai dengan pendapat Nurhadi dkk (2004: 58) yang menyatakan bahwa "PBL dikembangkan terutama untuk membantu siswa mengembangkan kemampuan berpikir, memecahkan masalah dan keterampilan intelektual, belajar tentang berbagai peran orang dewasa melalui pelibatan mereka dalam pengalaman nyata atau simulasi dan menjadi pembelajar yang otonom dan mandiri”.

PBL dapat meningkatkan kemampuan berpikir kritis siswa, karena pada PBL siswa dibiarkan untuk menemukan masalah sehingga siswa lebih bisa memahami permasalahan tersebut. Dari pemahaman siswa itu, kemampuan siswa dalam merumuskan suatu permasalahan juga menjadi lebih baik. Guru lebih melibatkan siswa dalam proses pembelajaran, sehingga siswa menjadi lebih aktif dalam proses pembelajaran. Selain itu, dalam PBL kemampuan siswa dalam mengambil keputusan dikembangkan. Apabila kemampuan dalam mengambil keputusan meningkat, maka pengambilan keputusan oleh siswa dalam mencari jawaban atas permasalahan yang diberikan oleh guru akan menjadi lebih baik. PBL juga menjadikan siswa mempunyai tanggung jawab tentang pembagian tugas dalam anggota kelompoknya, sehingga tugas yang diberikan oleh guru dapat terselesaikan dengan baik. Hal ini didukung oleh pendapat Riyanto (2009: 285) yang menyatakan bahwa "PBL adalah suatu model pembelajaran yang menuntut peserta didik untuk berpikir kritis, memecahkan masalah, belajar secara mandiri, dan menuntut keterampilan berpartisipasi dalam tim".

Hasil penelitian pada siklus I dan II menunjukkan bahwa PBL dalam kerangka lesson study dapat meningkatkan hasil belajar siswa. Hal ini dapat dilihat dari nilai rata-rata post-test siswa pada siklus II meningkat dibandingkan dengan nilai rata-rata pre-test pada siklus I dan nilai rata-rata post-test siswa pada siklus I. Nilai rata-rata pre-test siswa pada siklus I sebesar 73,47 kemudian nilai rata-rata post-test siswa pada siklus I sebesar 81,39 selanjutnya nilai rata-rata post-test siswa pada siklus II sebesar 91,25. Hasil rata-rata penilaian afektif siswa pada siklus II meningkat dibandingkan dengan penilaian afektif siklus I. Penilaian afektif siswa meliputi kehadiran siswa, kepribadian, kejujuran dan keaktifan, pada siklus I rata-rata penilaian afektif siswa sebesar 79,75\% kemudian pada siklus II sebesar 93,29\%. Dan hasil rata-rata penilaian psikomotorik siswa pada siklus II meningkat dibandingkan dengan penilaian afektif siklus I. Penilaian afektif siswa meliputi kemampuan mengerjakan soal dalam diskusi kelompok dan kemampuan mempresentasikan hasil diskusi kelompok, pada siklus I rata-rata penilaian psikomotorik siswa sebesar $74,31 \%$ kemudian pada siklus II sebesar $88,19 \%$. Rata-rata hasil belajar siswa ranah kognitif, afektif dan psikomotorik pada siklus I sebesar 78,48\% kemudian pada siklus II sebesar 90,91\%. 
Tabel 2. Perbandingan Persentase Hasil Nilai Kognitif Siswa

\begin{tabular}{|c|c|c|c|}
\hline \multirow{3}{*}{ Nilai } & \multicolumn{3}{|c|}{ Jumlah Siswa } \\
\hline & \multicolumn{2}{|c|}{ Siklus I } & \multirow{2}{*}{$\frac{\text { Siklus II }}{\text { Post-test }}$} \\
\hline & Pre-test & Post-test & \\
\hline $\mathrm{n} \geq 80$ & 12 & 26 & 36 \\
\hline $\mathrm{n}<80$ & 24 & 10 & 0 \\
\hline Jumlah siswa tuntas & 12 & 26 & 36 \\
\hline Persentase ketuntasan & $33,3 \%$ & $72,2 \%$ & $100 \%$ \\
\hline
\end{tabular}

Penerapan PBL dalam kerangka lesson study dapat meningkatkan hasil belajar karena dalam penerapan PBL siswa dituntut untuk belajar secara aktif dan mandiri dalam mengembangkan kemampuan berpikir kritis untuk memecahkan masalah baik secara individu maupun kelompok, sehingga siswa dapat lebih mudah memahami materi pelajaran. Penerapan PBL diperkuat dengan tahapan-tahapan dalam lesson study, yaitu: (1) Perencanaan (plan); (2) Pelaksanaan dan pengamatan (do); dan (3) Refleksi (see) menjadikan kualiatas pembelajaran yang dilakukan oleh guru dan aktivitas belajar siswa dapat meningkat secara efektif. Hal ini karena (1) pengembangan lesson study dilakukan dan didasarkan pada hasil "sharing" pengetahuan profesional yang berlandaskan pada praktik dan hasil pengajaran yang dilaksanakan para guru; (2) penekanan mendasar pada pelaksanaan suatu lesson study adalah agar para siswa memiliki kualitas belajar; (3) kompetensi yang diharapkan dimiliki siswa, dijadikan fokus dan titik perhatian utama dalam pembelajaran di kelas; (4) berdasarkan pengalaman real di kelas, lesson study mampu menjadi landasan bagi pengembangan pembelajaran; dan (5) lesson study akan menempatkan peran para guru sebagai peneliti pembelajaran (Siddik, 2013).

Dengan melaksanakan lesson study para guru dapat (1) menentukan kompetensi yang perlu dimiliki siswa, merencanakan dan melaksanakan pembelajaran (lesson) yang efektif; (2) mengkaji dan meningkatkan pelajaran yang bermanfaat bagi siswa; (3) memperdalam pengetahuan tentang mata pelajaran yang disajikan para guru; (4) menentukan standar kompetensi yang akan dicapai para siswa; (5) merencanakan pelajaran secara kolaboratif; (6) mengkaji secara teliti belajar dan perilaku siswa; (7) mengembangkan pengetahuan pembelajaran yang dapat diandalkan; dan (8) melakukan refleksi terhadap pengajaran yang dilaksanakannya berdasarkan pandangan siswa dan koleganya (Siddik, 2013).

Dengan melaksanakan lesson study aktivitas belajar siswa dalam belajar menjadi lebih kondusif dan termotivasi dalam mengikuti proses pembelajaran. Lesson study merupakan suatu cara yang efektif yang dapat meningkatkan kualitas mengajar guru dan pada akhirnya akan meningkatkan hasil belajar siswa (Siddik, 2013).

\section{SIMPULAN DAN SARAN}

\section{Simpulan}

Penerapan PBL dalam kerangka lesson study pada siswa kelas XI Akuntansi SMK Negeri 1 Malang berhasil dilaksanakan dengan baik. Hasil observasi keterlaksanaan pada siklus I pada kategori baik sedangkan hasil observasi ketelaksanaan pada siklus II pada kategori sangat baik.

Penerapan PBL dalam kerangka lesson study dapat meningkatkan kemampuan berpikir kritis siswa, hal ini dapat dilihat dari peningkatan nilai hasil observasi kemampuan berpikir kritis siswa siklus I dan siklus II. Pada siklus I hasil observasi siswa pada kategori cukup, skor terendah pada indikator melakukan diskusi dan menghargai orang lain, sedangkan pada siklus II hasil observasi kemampuan berpikir kritis siswa pada kategori baik, skor terendah masih pada indikator melakukan diskusi dan menghargai orang lain. 
Penerapan PBL dalam kerangka lesson study dapat meningkatkan hasil belajar siswa, hal ini dapat dilihat dari rata-rata penilaian ranah kognitif, afektif dan psikomotorik siswa pada siklus II meningkat dibandingkan dengan rata-rata penilaian ranah kognitif, afektif dan psikomotorik siswa pada siklus I.

\section{Saran}

Bagi guru akuntansi khususnya mata pelajaran siklus akuntansi perusahaan dagang disarankan untuk menerapkan PBL dalam kerangka lesson study secara intensif dan berkesinambungan karena melalui penerapan PBL dalam kerangka lesson study dapat meningkatkan kemampuan berpikir kritis dan hasil belajar siswa serta kualitas pembelajaran di dalam kelas.

Bagi sekolah hendaknya memberi kebijakan mengenai penerapan PBL dalam kerangka lesson study secara berkesinambungan sehingga dapat meningkatkan kualitas pembelajaran di dalam kelas terutama untuk meningkatkan kemampuan berpikir kritis dan hasil dan hasil belajar siswa.

Bagi peneliti selanjutnya hendaknya meneliti lebih lanjut mengenai penerapan PBL dalam kerangka lesson study untuk meningkatkan kemampuan berpikir kritis siswa terutama pada indikator kemampuan berpikir kritis siswa yang masih rendah yaitu melakukan diskusi dan menghargai orang lain, dengan tempat dan subyek yang berbeda serta dapat mengikut sertakan para guru dan kepala sekolah dalam kegiatan lesson study yang dilaksanakan.

\section{DAFTAR RUJUKAN}

Arikunto, S., Suhardjono, \& Supardi. 2009. Penelitian Tindakan Kelas. Jakarta: PT Bumi Aksara.

Herlanti, Y. 2010. Bisakah Penelitian Tindakan Kelas dan Lesson Study Digabungkan. (Online), (http://yherlanti.wosdpress.com/2010/09/03/bisakah-penelitian-tindakan-kelas-danlesson-study-digabungkan), diakses pada 20 Desember 2014.

Kieso, E., Donald. Weygandt, J. Jerry \& Kimmel, D. Paul. 2009. Accounting Principles (Pengantar Akuntansi). Jakarta: Salemba Empat.

Moleong, J Lexi. 2002. Metodologi Penelitian Kualitatif. Bandung: PT Remaja Rosdakarya

Mukhlis, dkk. 2005. Pengembangan Life Skill Mahasiswa Melalui Pembelajaran Mata Kuliah Ekonomi Mikro Menengah dengan Pendekatan Berbasis Masalah (Problem Based Learning). Laporan Hasil Penelitian Program Hibah Kompetisi A2 Jurusan Ekonomi Pembangunan FE-UM.

Nurhadi, dkk. 2004. Pembelajaran Kontekstual dan Penerapannya

Reinstein, Alan \& Bayou, E., Mohamed. 1997. Critical Thinking In Accounting Education: Processes, Skills, and Applications. Managerial Auditing Journal, 12/7: 336-342.

Riyanto, Yatim. 2009. Paradigma Baru Pembelajaran. Surabaya: Kencana.

Siddik, Muhammad. 2013. Lesson Study Sebagai Model Pembinaan Guru. Artikel, (Online), (http://sumut.kemenag.go.id/index.php?a=artikel\&id=12030\&t=2553), diakses 20 desember 2014.

Syamsuri, I. \& Ibrohim. 2008. Lesson Study (Study Pembelajaran): Model Pembinaan Pendidikan Secara Kolaboratif dan Berkelanjutan Dipetik dari Program SISTTEMSJICA di Kabupaten Pasuruan-Jawa Timur (2008). Malang: FMIPA UM. 